\title{
THE EFFECT OF DURATION OF FLUSHING PERIOD AND STOCKING RATE ON THE REPRODUCTIVE PERFORMANCE OF SCOTTISH BLACKFACE EWES
}

\author{
B. G. MERRELL
}

MAFF/ADAS, Redesdale EHF, Rochester, Otterburn, Newcastle upon Tyne NE19 ISB

\section{INTRODUCTION}

$\mathbf{I}$ is generally accepted that the provision of a high plane of nutrition pre-mating (flushing), associated with an increase in ewe live weight and body condition score, will result in a higher lambing rate. A previous trial carried out by ADAS, at Redesdale EHF, had clearly demonstrated the beneficial effect on ewe reproductive performance of flushing Scottish Blackface ewes for a 5-week period pre-mating, on improved hill pastures (hill reseeds) rested mid August to mid October (Davies, 1987). Accumulated herbage is a finite resource, and both duration of flushing period and stocking rate will influence the amount of herbage remaining during the post-mating period. This in turn has implications for foetal implantation, embryo survival and lambing rate.

The trial reported studied, over 3 years (1986 to 1988), the effects of flushing hill ewes for either $5(\mathrm{~L})$ or $2(\mathrm{~S})$ weeks and stocked at either $10(1)$ or $18(\mathrm{~h})$ ewes per ha on lambing rate, in the context of accumulated herbage mass.

\section{MATERIAL AND METHODS}

In mid October, each year, 200 regular aged $(2.5$ to 6.5 years) Scottish Blackface ewes were allocated on the basis of age, body condition and live weight to four balanced treatment groups.
Two groups, of 50 ewes each, were confined within hill reseeds 5 weeks pre-mating and were stocked at either 10 or 18 ewes per ha. The remaining two groups of ewes were returned to hill grazing for a further 3 weeks before being confined on the hill reseeds, again stocked at 10 or 18 ewes per ha.

Two areas of improved pasture based on perennial ryegrass, timothy and white clover and of similar botanical composition were divided using electrified sheep netting to produce four treatment paddocks.

Each paddock received $40 \mathrm{~N}+20 \mathrm{P}_{2} \mathrm{O}_{5}+60 \mathrm{~K}_{2} \mathrm{O} \mathrm{kg} /$ ha in mid August each year. The sward height within each paddock was adjusted, as necessary, by manipulating sheep and cattle grazing to produce a sward height of between 7 and $8 \mathrm{~cm}( \pm 0 \cdot 5) 5$ weeks pre-mating.

Harnessed rams were introduced, one per treatment group, on 20 November for a 49-day mating period. The rams were moved between the groups every 4 to 6 days using a Latin-square design.

At the end of the tupping period the treatment groups were amalgamated and returned to hill grazing until mid February. Thereafter, following pregnancy diagnosis, twin-bearing ewes were housed for preferential feeding during the last 8 weeks of pregnancy.

All ewes were allowed free access to supplementary food blocks from early January and single-bearing ewes continued on this regime after scanning and were given hay during storm conditions. Twin-bearing ewes were

TABLE 1

Available herbage (mean sward height, cm)

Treatment paddocks

\begin{tabular}{|c|c|c|c|c|}
\hline & $\mathrm{Ll}$ & Lh & Sl & Sh \\
\hline 5 weeks pre-mating & $7 \cdot 27 \dagger$ & $7 \cdot 29 \dagger$ & $7 \cdot 31$ & $7 \cdot 29$ \\
\hline 2 weeks pre-mating & $5 \cdot 92$ & $5 \cdot 71$ & $7.58 \dagger$ & $7 \cdot 60 \dagger$ \\
\hline Mating & $5 \cdot 25$ & $4 \cdot 55$ & $6 \cdot 49$ & $6 \cdot 53$ \\
\hline 4 weeks post mating & $3 \cdot 68$ & $3 \cdot 29$ & 3.94 & $3 \cdot 75$ \\
\hline 7 weeks post mating & $3 \cdot 01$ & $2 \cdot 20$ & $2 \cdot 99$ & $2 \cdot 48$ \\
\hline
\end{tabular}


given hay ( $1.0 \mathrm{~kg}$ fresh material per head per day) and supplementary concentrates, initially at a rate of $0.25 \mathrm{~kg}$ increasing gradually to $0.80 \mathrm{~kg} 14$ days before lambing.

The ewes were weighed (to nearest $0.1 \mathrm{~kg}$ ) and body condition scored (Russel, Doney and Gunn, 1969) 5 and 2 weeks pre-mating, also at the start and at the end of the mating period.

Sward height was assessed, using a sward stick, at weekly intervals during the period October to January. Sufficient records were taken to satisfy a statistical model proposed by Ridout (1986) to ensure accuracy of recording.

\section{RESULTS}

The mean sward height achieved on each paddock at the start of the flushing period, and changes in sward height, are given in Table 1. The paddocks used for the 2-weeks flushing treatment ( $\mathrm{Sl}$ and Sh groups) continued to accumulate herbage during the additional 3 weeks the ewes remained on hill grazings and had a mean sward height of $7.59 \mathrm{~cm}$ at the start of the flushing period. Thereafter, the sward height on all paddocks declined and the rate of decline was directly related to the duration of the flushing period and the stocking rate imposed.

During the course of the trial, 11 ewes died or were discarded for reasons of ill-health. The number of ewes remaining in each group were: $\mathrm{Ll}, \mathrm{Sl}$ and $\mathrm{Lh}, 148$ and Sh 145.

Mean ewe live weight and weight change data are summarized in Table 2. Treatment differences were tested by analysis of variance.

Over the 5 weeks prior to the start of the mating period ewes in all groups either maintained or increased in mean live weight and body condition (Table 3 ). The increases in group $\mathrm{Ll}$ were greater than in groups $\mathrm{Lh}$ and Sh which in turn were greater than in group Sl.
Increases in live weight were not significantly different, whereas the increase in body condition of ewes in the Ll group was significantly greater than that of ewes in groups $\mathrm{Lh}, \mathrm{Sl}$ and $\mathrm{Sh}(P<0 \cdot 01)$.

Mean ewe body-condition scores and changes in body condition are summarized in Table 3. Differences in condition scores were tested by $\chi^{2}$ analysis of the distribution of ewes in each fat score ( 1 to 5 ) by quarter divisions.

At the start of the mating period there was no significant difference in the live weight of ewes (Table 2). However, the body condition of ewes in group LI was significantly greater than that of ewes in groups Lh and Sl $(P<0 \cdot 01)$, which did not differ significantly from each other. The body condition of ewes in the Sh group was intermediate and did not differ significantly from ewes in the $\mathrm{Ll}$ and $\mathrm{Lh}$ groups.

By 7 weeks post mating ewes in the Lh group had lost more weight and were of significantly lower live weight than ewes in the $\mathrm{Ll}, \mathrm{Sl}$ and $\mathrm{Sh}$ groups $(P<0.05)$, between which there were no significant differences.

The number of lambs born (both alive and dead) and the mean lambing rate of ewes in each treatment group are given in Table 4. Differences in mean lambing rate were subjected to analysis of variance and differences in litter size were tested by $\chi^{2}$ analysis of the distribution of zero to three lambs born.

The mean lambing rate of ewes in the Lh group was lower than that of ewes in the $\mathrm{Ll}$ and $\mathrm{Sh}$ groups but differences were not significant. The mean lambing rate of ewes in the SI group was significantly higher than ewes in the Lh group $(P<0.05)$. This was due to a greater number of multiple births in the Sl group.

\section{DISCUSSION}

A previous trial had shown that the provision of a relatively high plane of nutrition, in the form of

TABLE 2

Mean live weight and weight change of ewes around the point of mating $(\mathrm{kg})$

Treatment groups

\begin{tabular}{|c|c|c|c|c|c|}
\hline & & & & & \multirow[b]{2}{*}{ s.e.d. $(6$ d.f. $)$} \\
\hline & $\mathbf{L l}$ & $\mathrm{Lh}$ & SI & Sh & \\
\hline \multicolumn{6}{|l|}{ Live weight } \\
\hline 5 weeks pre-mating & $56 \cdot 5$ & $56 \cdot 4$ & $56 \cdot 5$ & $56 \cdot 5$ & $0 \cdot 141$ \\
\hline 2 weeks pre-mating & $56 \cdot 8$ & $56 \cdot 8$ & $56 \cdot 3$ & $56 \cdot 8$ & $0 \cdot 216$ \\
\hline Mating & $57 \cdot 5$ & $56 \cdot 6$ & $56 \cdot 5$ & $56 \cdot 9$ & 0.761 \\
\hline 7 weeks post mating & $55 \cdot 5^{\mathrm{a}}$ & $51 \cdot 4^{\mathrm{b}}$ & $55 \cdot 2^{\mathrm{a}}$ & $53 \cdot 9^{a}$ & 0.710 \\
\hline \multicolumn{6}{|l|}{ Live-weight change } \\
\hline $\begin{array}{l}5 \text { weeks pre- to mating } \\
\text { Mating to } 7 \text { weeks }\end{array}$ & $+1 \cdot 0$ & +0.3 & 0 & $+0 \cdot 4$ & 0.731 \\
\hline post mating & $-2 \cdot 0^{\mathrm{a}}$ & $-5 \cdot 3^{b}$ & $-1 \cdot 4^{\mathrm{a}}$ & $-3 \cdot 0^{a}$ & 0.792 \\
\hline $\begin{array}{l}\text { Means with differen } \\
(P<0.05)\end{array}$ & su & cripts & are & gnificantly & $\operatorname{diffe}$ \\
\hline
\end{tabular}


TABLE 3

Mean body condition score and body condition-score change of ewes around the point of mating

Treatment groups

\begin{tabular}{|c|c|c|c|c|c|}
\hline & & & & & \multirow[b]{2}{*}{$\chi^{2}$ cal } \\
\hline & $\mathrm{Ll}$ & Lh & Sl & Sh & \\
\hline \multicolumn{6}{|l|}{ Condition score } \\
\hline 5 weeks pre-mating & $2 \cdot 57$ & $2 \cdot 57$ & $2 \cdot 57$ & $2 \cdot 58$ & $2 \cdot 96$ \\
\hline 2 weeks pre-mating & $2 \cdot 69$ & $2 \cdot 61$ & $2 \cdot 62$ & $2 \cdot 63$ & $22 \cdot 68^{*}$ \\
\hline Mating & 2.75 & $2 \cdot 69$ & $2 \cdot 66$ & $2 \cdot 72$ & $30 \cdot 90^{* *}$ \\
\hline 7 weeks post mating & $2 \cdot 63$ & $2 \cdot 41$ & $2 \cdot 57$ & $2 \cdot 49$ & $60 \cdot 06^{* * *}$ \\
\hline \multicolumn{6}{|l|}{ Condition-score change } \\
\hline $\begin{array}{l}5 \text { weeks pre- to mating } \\
\text { Mating to } 7 \text { weeks }\end{array}$ & $+0 \cdot 18$ & $+0 \cdot 12$ & $+0 \cdot 09$ & $+0 \cdot 14$ & $38 \cdot 25^{* *}$ \\
\hline post mating & $-0 \cdot 12$ & -0.28 & -0.09 & -0.23 & $56 \cdot 82^{* * *}$ \\
\hline
\end{tabular}

TABLE 4

Number of ewes which produced different numbers of lambs at birth and mean lambing rates

Treatment groups

No. of ewes

No. of lambs

born

\begin{tabular}{|c|c|c|c|c|c|}
\hline 0 & 7 & 6 & 5 & 11 & \\
\hline 1 & 53 & 81 & 42 & 48 & \\
\hline 2 & 88 & 61 & 97 & 85 & 33.83 \\
\hline 3 & 0 & 0 & 4 & 1 & \\
\hline an lambing rate & $1.55^{\mathrm{ab}}$ & $1 \cdot 37^{\mathrm{a}}$ & $1 \cdot 68^{\mathrm{b}}$ & $1.52^{\mathrm{ab}}$ & $\begin{array}{c}0.09 \\
0 . d .\end{array}$ \\
\hline
\end{tabular}

$\begin{array}{ccccc}\text { Ll } & \text { Lh } & \text { Sl } & \text { Sh }\end{array} \quad \chi^{2}$ cal

${ }^{\mathrm{a}, \mathrm{b}}$ Means with different superscripts differ significantly $(P<0 \cdot 05)$.

accumulated good quality pasture, available for 5 weeks pre-mating, increased lambing rate from about 1.00 to 1.53 (Davies, 1987). Many hill and upland farms have insufficient inbye land or improved hill pasture to allow ewes to be flushed for 5 weeks and a shorter duration of flushing period is of commercial interest.

In addition, accumulated herbage is a finite resource which may be better utilized by reducing the duration of the flushing period and by making available more herbage post mating.

The provision of good quality herbage pre-mating influenced both body condition and live weight. Overall flushing for 5 weeks produced about twice the gain in live weight that flushing for 2 weeks produced, but the difference was reduced to nil at the higher stocking rate. Increases in live weight and body condition of ewes on all treatments were relatively small and this probably reflects the moderately good condition of the ewes at the start of the trial. A similar low level of weight gain by ewes in moderately good condition has been shown by Gunn and Doney (1983).
In the trial reported, mating was not to a synchronized oestrus. If mating did not take place until the end of the first cycle or the beginning of the next, live weight and body condition of ewes, particularly in the Lh group, may have been falling at the time of mating due to a decline in sward height (Table 1), limiting herbage intake. This in turn could reduce ovulation rate and lambing rate. However, Gunn, Doney and Smith (1984) have shown that where a period of high food intake is followed by a short period of live weight maintenance feeding, the effect on ovulation rate is reduced where the period of high level feeding has been in excess of 27 days. It is therefore unlikely that ewes in the Lh group would have had lower ovulation rates than ewes in the other groups.

The mean lambing rate of ewes in the LI group was the same as that reported by Davies (1987) in a previous trial where ewes drawn from the same source were managed on the same system pre-mating.

In the present trial the mean condition score of ewes in all groups was $2 \cdot 57,5$ weeks pre-mating and had risen to 
2.71 at the start of the mating period. Ewes in this level of body condition are probably above the critical band of condition within which there would be an expected positive ovulation response to a higher plane of pre-mating nutrition additional to that related to the condition itself (Gunn et al., 1984).

Although ovulation rate was not assessed in the reported trial, the findings of Gunn et al. (1984) would suggest that the differences observed in lambing rate were not a direct consequence of differences in ovulation rate. All ewes were in good body condition at the start of the mating period and ovulation rate would be expected to be similar for ewes in all groups.

Differences in the level of fertilization failure are also unlikely to explain difference in lambing rate as a period of high level of feeding at some stage during the 36 days prior to mating has been shown to reduce fertilization failure (Gunn et al., 1984). Fertilization failure, or very early embryo total mortality, is also known to be very low in ewes of good body condition ( $\geqslant 2 \cdot 75$ ) (Gunn, Doney and Russel, 1972).

The observed differences in lambing rate are most likely to reflect differences in embryo loss, particularly during the first 30 days post mating of the individual ewe.

Seven weeks after the start of the mating period the sward height on the Ll, Lh, Sl and Sh paddocks had fallen to $3 \cdot 01,2 \cdot 20,2.99$ and $2 \cdot 48 \mathrm{~cm}$, respectively. A sward height of below $3.5 \mathrm{~cm}$ has been shown to reduce herbage intake by Scottish Blackface ewes around the point of mating. A low post-mating intake can result in a reduction in live weight and body condition. This has been shown to compromise embryo growth rate, and induce a higher rate of ova wastage, resulting in a reduced lambing rate.

In the reported trial there was a clear relationship between live weight and body condition loss up to 7 weeks post mating and mean lambing rate. Ewes which lost the most weight and body condition post mating (Tables 2 and 3) produced the least number of lambs and conversely ewes which lost less live weight and body condition produced the most lambs (Table 4). Treatment differences in lambing rate were mainly not significant but the proportional increase in lambing rate of 0.13 between the $\mathrm{Ll}$ and $\mathrm{SI}$ groups is probably sufficiently large to be of commercial importance.

The results of this trial would suggest that mean lambing rate can be increased by flushing ewes in moderately good body condition (ca. 2.57 ) for only 2 weeks pre-mating compared with a 5-week flushing period. However, the advantage was lost when stocking rate was increased from 10 to 18 ewes per ha.

At the higher stocking rate ewes would have benefited from supplementary feeding when sward height fell below $3.5 \mathrm{~cm}$, or from a reduction in stocking rate during the post-mating period.

\section{REFERENCES}

Davies, M. H. 1987. Flushing hill ewes. In Efficient Sheep Production from Grass (ed. J. E. Pollot), Occasional Symposium, British Grassland Society, No. 21.

Gunn, R. G. and Doney, J. M. 1983. A note on the influence of pattern on live weight and body condition recovery between weaning and mating on food consumption and reproductive performance of Scottish Blackface ewes. Journal of Agricultural Science, Cambridge 81: 189-191.

Gunn, R. G., Doney, J. M. and Russel, A. J. F. 1972. Embryo mortality in Scottish Blackface ewes as influenced by body condition at mating and by post-mating nutrition. Journal of Agricultural Science, Cambridge 79: 19-25.

Gunn, R. G., Doney, J. M. and SMith, W. F. 1984. The effect of different durations and times of high-level feeding prior to mating on the reproductive performance of Scottish Blackface ewes. Animal Production 39: 99-105.

Ridout, M. 1986. Grass and Forage News. Number $86 / 10$.

Russel, A. J. F., Doney, J. M. and Gunn, R. G. 1969. Subjective assessment of body fat in live sheep. Journal of Agricultural Science, Cambridge 72: 451-454. 